\title{
Social Position, Ideology, and Distributive Justice
}

\author{
Leo d'Anjou, ${ }^{1,2}$ Abram Steijn, ${ }^{1}$ and Dries Van Aarsen ${ }^{1}$
}

This paper addresses two important questions regarding distributive justice. First we ask whether people use standards or principles of distributive justice regarding the allocation of income. The study confirms our expectation that there are at least two principles, viz., the merit and the need principle. Our data show that there is no generally held consensus about the applicability of these two principles. Second, we looked for explanations to explain variations in adherence to these principles. The literature suggests five different theses: 1 . self-interest; 2. ideology; 3. enlightenment; 4. historical shift; and 5. gender. Results provide qualified support for the Theses 1, 2 and 4. Class, ideology, and age affect the preferences for the principles of justice. Further elaboration suggests the data point to a specific version of the self-interest thesis, viz., the underdog thesis. Theses 3 and 5 are not confirmed. Implications of these findings are discussed.

KEY WORDS: distributive justice; merit; need; class; ideology.

\section{INTRODUCTION}

"Justice is a central moral standard in social life...the issues it addresses are fundamental to social life" (Cohen, 1986). One of the central issues in the discussion on justice concerns the distribution of the benefits and burdens of living together. In this distribution people expect to get what their equals get (Homans, 1961, 1974) or in the words of Berger et al. (1972, p. 144): "the essential idea [of distributive justice] is that actors who are

${ }^{1}$ Erasmus Universiteit, Rotterdam, The Netherlands.

${ }^{2}$ All correspondence should be sent to L. J. M. d'Anjou, Sociale Faculteit, M 05-10, Erasmus Universiteit, Postbus 1738, 3000 DR Rotterdam, The Netherlands. 
similar in terms of socially defined and valued characteristics expect to be similar in their rewards." For this expectation they compare what they put into social life - in Homans's words: their investments and costs-with what they get out of it-their rewards. These input-outcome comparisons are based on referential structures (Berger et al., 1972) which contain information on what is regarded as an input and what as an outcome and what the social value of those inputs and outcomes is. These structures function as standards of entitlement (Lerner, 1987). They define what people in certain situations or with certain characteristics are entitled to or deserve.

Research on distributive justice shows that people actually use consensually held referential structures or justice rules (Cook, 1975) in evaluating the distribution of valued resources, such as love, status, and different kinds of goods (Törnblom and Foa, 1983). Such rules are also used when the distribution of income is evaluated (Jasso and Rossi, 1977; Alves and Rossi, 1978; Hermkens and Boerman, 1989). Although in the "income-justice" studies references are often made to underlying principles of justice, such as need or merit, the existence of such principles is only assumed, not assessed. In this paper we look into the question of whether people use principles like merit or need regarding the distribution or allocation of income.

The second question in this study concerns consensus itself. Is there a consensus on the applicability of these justice principles or are there differences in this respect between individuals or groups in society? Earlier research (Alves and Rossi, 1978; Berting et al., 1986) indicated that individuals with a higher income are more inclined to allocate income on the basis of criteria reflecting merit considerations while those with a lower income opt for need criteria. Hermkens and Boerman (1989), however, found a less clear division in preferences for allocation criteria. All in all, it seems that the position of individuals in society may affect the preference for justice criteria and principles. A problem with the aforementioned studies is that societal position is measured only by income. In this paper we also take class as a measure for assessing the location of individuals in the societal structure because class still seems to be important as a determinant of attitudes and preferences (Marshall et al., 1988).

At the same time we acknowledge that class and income explain only a limited part of the variation in preference for justice rules and principles. In research on distributive justice, ${ }^{3}$ therefore, other determinants are put

${ }^{3}$ We refer here also to studies on the question how people justify existing inequalities, because judging these as just and fair is another way of expressing opinions and judgments on the fairness or justice of the distribution of economic resources. In other words, economic equality is the mirror image of social justice or as Rytina (1986) stated: "The dominant problematic of justice in sociology is an interplay of inequality and sentiment that supports or undermines it." 
forward. As Shepelak (1989) shows, ideological beliefs play a role as well. Beliefs connect background variables, such as occupation, income, and education, with the evaluation of inequality. Robinson and Bell (1978) came to the same conclusion. They, moreover, took enlightenment (measured by education) and a historical shift to egalitarianism (measured by age) as independent variables into their analysis. Finally, the work of Gilligan (1982) suggests that men and women differ in their judgments of justice questions. The foregoing suggests that there might not be a consensus regarding the application of justice criteria. In this paper we assess whether this is the case and, if there is no consensus, we look into an explanation for this lack of consensus. In summary, this paper addresses the following questions: (i) Do people use standards or principles of justice regarding the allocation of income? (ii) Is there a consensus regarding the applicability of these principles and, if not, which explanations of this lack of consensus are the most promising?

\section{THEORETICAL FRAMEWORK}

This section on theory is divided into two subsections following the two questions above. First, we elaborate the concept "distributive justice principle" and the two principles, merit and need, that we use in our study. Second, we develop five theses, each of which puts forward a (partial) explanation of why people differ in their preferences for the merit and the need principles of justice. Finally, we bring these five theses together in a conceptual model.

\section{Distributive Justice Principles: Merit and Need}

Specific justice principles are part of a more encompassing concept of justice. One of the problems in the literature on justice, however, is the lack of conceptual clarity and theoretical unity (Cook, 1987). Bell and Schokkaert (1992), e.g., point out that the concept of equity has a different meaning in psychology, economics, and law. As there are also important terminological confusions (see Footnote 4), it is necessary that we make clear what we mean by "justice principle" and so clarify the topic of this paper.

Justice is a container concept and "seems to mean different things to different people and in different circumstances" (Törnblom, 1992, p. 177). As Törnblom contends, it lacks a distinctive or "true" meaning. The concept "distributive justice" is, however, less indistinct and refers, in gen- 
eral, to a just state of affairs concerning the distribution of benefits and burdens (Miller, 1976; Rawls, 1973). Such a distribution is perceived as just or fair if it is regulated by accepted rules. At this point, distributive justice is often equated with equality; a usage that, as Hochschild (1981) rightly remarks, "blurs concepts that should be kept separate." In the sphere of distributive justice equality is either absolute or strict equality, i.e., the general rule that "all people may legitimately make the same claims on social resources" (p. 46), or relative or bounded equality, i.e., the general rule that "equals must be treated equally and unequals unequally" (Aristoteles, citated in Cullen, 1992, p. 15). The latter means that making differences of some kind does not turn a particular distribution into an unjust one. Hochschild, moreover, pointed out that people accept some form of differentiation as the guiding rule in economic affairs.

Distributive justice regarding the allocation of income, primarily an economic affair, thus concerns the specific rules or norms that make an allocation a just one. There are two sets of these rules, viz., substantive and formal ones (Cohen and Greenberg, 1982; Buchanan and Mathieu, 1986). The first set contains the rules that state which differences (acts or attributes) between people are deemed relevant for the allocation of income. It represents, in Hamilton and Rytina's (1980) words, the domain of inputs. The second set consists of the rules that state the way in which these differences are translated into differences in income; in Hamilton and Rytina's terminology, the linkage rules.

Homans's notion of proportionality between investments and profits which "lies at the heart of distributive justice" points to the formal side of distributive justice $(1961,1974)$. Proportionality is a formal rule that in a quantitative way links the domain of inputs to the domain of outcomes, in our case income. Markovsky (1985) made the same distinction in this respect, viz., between scales of rewards and investments and a referential rule such as proportionality (see also Schaeffer's distinction between material and procedural operands and a referential rule such as proportionality which is, however, not the only possible linkage rule; Schaeffer, 1990). Proportionality can be formulated as $y(x)$, where $y$ is the outcome, e.g., income, and $\mathrm{x}$ an input, i.e., an attribute, such as education, which justifies a dif-

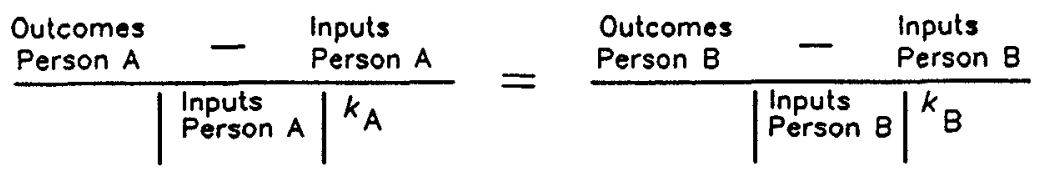

Fig. 1. The "Walster" equity formula. 
ferent outcome. This proportionality rule is elaborated in the equity tradition within social justice research and formalized in equity formulas, such as the one devised by Walster and Walster (1975) (Fig. 1).

In this paper, however, we are not concerned with the formal principle of proportionality but with the substantive side of distributive justice or with the differences that people think may legitimately lead to differences in income; in Homans's (1961) words: “[people's] ideas of what legitimately constitutes investment, reward, and cost, and how these are to be ranked" (p. 246). Above, we have referred to these ideas as distributive justice rules. The acceptance or rejection of each of these rules is, as stated in our Introduction, not based on strictly individual preferences but is guided by consensually held principles or referential standards. ${ }^{4}$ These distributive justice principles underlie the choice or preferment of specific rules out of a multitude of rules regarding the attributes and acts of people that are considered to be relevant for the distribution of income. More specifically, the choice concerns social status characteristics, such as sex and occupation; investments, like education or initiative; and need considerations, like being handicapped or number of dependent children. This paper, now, regards these substantive principles of distributive justice.

Generally, three of these substantive principles of justice are stated, viz., equality, merit, and need (Homans, 1982; Tornblom and Foa, 1983). Equality is, however, a problematic concept because like justice, it has no clear meaning. It is sometimes formulated as the preference for a more egalitarian distribution of resources (see, e.g., Ritzman and TomaskovicDevey, 1992). Others refer to equality as an end that must be reached as is the case with equality of opportunity. Regarding the allocation of income, equality means, as we have stated above, relative equality or differentiation between people according to accepted differences between them. It, thus, means that people may legitimately state varying claims on the amount of income they (ought to) receive based on differences between them

\footnotetext{
${ }^{4}$ The terminology on the input side of distributive justice is rather confusing. Deutsch (1985), for instance, discerns values of justice, such as equity, equality, and need, and rules or criteria for defining the values. Berger et al. (1972) refer to these values as referential structures (referential standards in the terms of Alwin, 1987) which provide the basis for defining the meaning of relevant characteristics. Others make the same distinction while using other terms. Cook (1975): distribution rules and dimensions of evaluation, such as seniority, skill, level of need, age, etc.; Hochschild (1981): norms of justice which form the basis for specific allocation decisions; Homans (1961, 1974, 1982): rule or rules of distributive justice and criteria such as investments and costs; Jasso and Rossi (1977) and Alves and Rossi (1978): principles and criteria of justice, etc. In this paper we will use "criteria" when we refer to the characteristics of people or of the situation in which they find themselves that are relevant for allocation of income, criteria such as education, initiative, seniority, age, or number of dependent children. The term "principle" is used when we refer to the dimension underlying the choice or preferment of these criteria.
} 
(Hochschild, 1981). Following Hochschild, we try to avoid terminological confusion and use the term "equality" for denoting strict equality. This implies in our case that equality is not a suitable substantive principle of justice; only "differentiation" principles count.

There are, in view of the allocation of income, two kinds of differences that may be accepted as the foundation of varying amounts of income. First, there are differences in social contributions which ought to be rewarded, leading to allocation of income "to each according to his deserts" (Miller, 1976). We call this the "merit" principle. Second, there are differences that ought to be compensated because all human beings have a right to exist "regardless of their inputs" (Schwartz, 1975). This leads to allocation of income "to each according to his needs" (Miller, 1976)-the "need" principle.

Allocation: To Each According to His Deserts-The Merit Principle. This justice principle justifies differences in income by pointing to the different contributions people make (or are perceived to make) in producing goods, services, and other valued things. Central to this concept of justice is the notion of contribution or merit, which means that differences in contribution to the social product ought to be rewarded. The merit principle depicts which of the different attributes or characteristics of people should be seen as relevant differences in contribution and should therefore be considered when allocating income. This concerns among other things differences in education, initiative, or taking responsibility. Together, all those things that are assumed to enhance productivity.

Allocation: To Each According to His Needs-The Need Principle. The need concept of justice acknowledges that people differ in their abilities to earn an income that will allow them and their family to live in a decent way. These differences in ability ought to be compensated for by giving those people more than they would receive in a completely free market situation. The allocation is thus based on the needs people have. Important in this respect are considerations regarding the level of social security benefits, the importance of being employed for the entitlement to an income, or the higher costs of being ill or disabled.

\section{Distributive Justice: Five Theses}

In the foregoing subsection we have stated that the allocation of income is evaluated as being fair if in this allocation accepted rules are used. In this subsection we begin by assuming that people differ with regard to the question which rules are acceptable and that these differences reflect differences in preference for the merit and the need principles of distribu- 
tive justice. The question is then what determines these different preferences. In the literature five theses are suggested that explain why people differ in their preferences for the merit and the need principles. These are (1) the self-interest thesis; (2) the ideology thesis; (3) the enlightenment thesis; (4) the historical shift thesis; and (5) the gender thesis. These theses are elaborated below. Two of these theses, i.e., self-interest and ideology, require more attention because they employ class and ideology concepts that are widely disputed.

\section{Self-Interest Thesis}

This thesis states a direct relationship between one's position in the social structure and one's attitudes. As such it originates in the work of Marx and Engels (1984) and Weber (1968) and is studied, among others, by Goldthorpe et al. (1969), Huber and Form (1973), Mackenzie (1973, 1974), Lockwood (1975), Robinson and Bell (1978), Kluegel and Smith (1986), Marshall et al. (1988), Grimes (1989), Svallfors (1991), Evans (1993). The thesis is also known as the structural theory (Mackenzie) or the underdog principle (Robinson and Bell). Robinson and Bell (1978, p. 128) who studied social judgments about the fairness or unfairness of inequality, state the essence of this thesis as follows: "individuals who objectively benefit from the stratification system in comparison with others are more likely to judge its inequalities to be just. Conversely, people who are objectively less well off are more likely to judge equality to be fair, since [this]...would result in their receiving more societal goods." This means that people have interests following from their location in the social structure and that these interests affect the way in which people justify allocation rules (or criteria). They accept a rule as legitimate and just if the rule concurs with their interests.

The locations in the societal structure, the social positions, are often conceptualized as class positions. As class is a disputed concept, we further elaborate this concept. A more straightforward way of assessing one's social position is taking income as the indicator of this position. Research (Alves and Rossi, 1978; Berting et al., 1986; Shepelak. 1989) indicates that this may even reflect interests with respect to the allocation of income more clearly than class and thus we also use income as an indicator of social position.

According to an important study, class is still a very important factor in shaping people's attitudes. Marshall et al. (1988, p. 267) explicitly state that "social class is to the fore among conceptions of collective identity. It is still the case that important differences in shared beliefs and values 
are structured more obviously by class than by other sources of social cleavage." The precise relationship between class and the preference for the merit or need principle is, however, less clear. Two reasons explain this: One is that although there is abundant research into the relationship between class and images of society, class is not often studied in relation to distributive justice. The second reason is the difficulty to produce a class concept that is generally accepted in the scientific community.

According to Wright (1979) there are three main class concepts: the American class concept based on gradation in the status of occupations; the Marxist class concept based on different relations in the sphere of production; and the Weberian concept of class based on different life chances in the economic (market) domain. The manner in which the stratification system of modern society has developed poses two important problems for each of these concepts. The first problem concerns what Wright (1989) calls "the embarrassment of the middle classes." A class concept has to accommodate both the quantitative growth of the middle classes and its diversification. The second problem is a consequence of how class position is commonly measured, viz., by occupation. As Drudy (1991, p. 26) states: "This obviously becomes increasingly a problem in an era of mass unemployment." An appropriate class concept must also accommodate the growing group of social security benefit recipients.

Weber's work on class in our view gives ample opportunity for devising a class concept that meets these problems. First, Weber (1968) speaks of a class situation when a number of people have in common a specific causal component of their life chances (the capability to dispose of material property or the possession of marketable skills) in the sphere of economic market relations. Weber's extension of the Marxist class concept with its emphasis on property relations with the skill component may lead to a class concept especially suited for the incorporation of the so-called new middle classes. Second, it is not very difficult to apply Weber's class concept to the existence of those who do not derive their position from a place in the domain of production, i.e., the recipients of social security benefits. This would simply mean adding a third causal component, viz., a legal right to income-Reich's (1964) new property. Although, it would not be impossible to incorporate this "new" class position in either the American class concept or in a Marxist one, this would mean bending these concepts more than is necessary with Weber's class concept.

Summarized, the self-interest thesis is based on the idea of different interests deriving from positions in the social structure each with it own justification. Some assets, such as property or marketable skills, give their possessors better life chances in the form of higher incomes and other social rewards. They tend to justify their advantages by pointing to the con- 
tributions to society they provide with these assets (the merit principle of justice). It is in their interest that the rewarding of their assets and the related justification remain as they are. Those who are less fortunate-the underdogs-will self-evidently tend to disagree. They will put other characteristics, theirs, forward as the basis for differences in social rewards and propose another justification. As the underdogs are less able to make a living with their assets they will benefit by emphasizing compensations for their deficits (the need principle). More specifically, the self-interest thesis predicts that the better one's class position in terms of life chances the more one will prefer the merit principle and the worse one's class position in this respect the more one will prefer the need principle. (Class is further elaborated and operationalized in the Methods section below.) The thesis also predicts that those with a higher income will prefer the merit principle and those with a lower income the need principle.

\section{Ideology Thesis}

This thesis is in fact a refinement of the self-interest thesis. Some researchers have pointed out that the supposed direct relationship between social position and attitudes is far to simple (Davis, 1979; Graetz, 1986). This assumed direct linkage ignores the fact that in daily life people use beliefs to interpret and evaluate reality and guide their actions. Beliefs function as cognitive frameworks (Smith and Stone, 1989) which provide rationales for people to cope with the situations in which they find themselves (Robinson and Bell, 1978). Beliefs can either be conceived as a broad concept encompassing values, perceptions, and attitudes, as Kluegel and Smith (1981) do, or as a more limited concept in which the use of the term belief is restricted to elements on the more general or abstract level of a culture, the ideological level. In the latter case these generalized ideological beliefs convince people that what exists is right and hence shape and organize their attitudes and preferences which are related to specific and concrete phenomena (Shepelak, 1989), i.e., the more mundane level of daily existence.

In this paper we opt for the limited concept in which a distinction is made between ideological beliefs on a general level and specific attitudes and preferences. There is an important difference between the two levels. Beliefs affect attitudes and preferences, but they do not determine them because ideological beliefs-as Weakliem (1993) points out-only affect "the probabilities of holding different opinions [and attitudes and preferences] by making some choices seem more plausible and natural than others" (p. 384). Agreement with some abstract idea does not imply 
commitment to specific concurring outcomes or policies (Rafferty and Hasenfeld, 1992). We, thus, discern on the one hand a set of beliefs concerning the way the economic system works (and which is judged as right) and on the other the guidelines people use in evaluating the allocation of income. The first we call-following Huber and Form (1973)-ideology and the second the principles of distributive justice.

Ideology is in turn affected by the structural position of people, indicated by other variables such as income, class, gender, and race (Huber Rytina et al, 1970; Huber and Form, 1973; Robinson and Bell, 1978; Kluegel and Smith, 1986, Shepelak, 1989). Through this double relationship (i.e., social position $\longrightarrow \rightarrow$ ideology; and ideology $\longrightarrow>$ justice principle) ideological beliefs connect people's social position to specific attitudes concerning inequality (see Robinson and Bell, 1978; Shepelak, 1989). As Rafferty and Hasenfeld (1992) state: "There is evidence that one's economic and social position accounts for one's beliefs and endorsement of government responsibility in solving social problems and commitment to the more specific principle that individuals are entitled to a basic standard of living" (p. 512). We assume that ideology plays the same connecting role with respect to justice principles.

Concerning the way the economic system works and how it affects the allocation of income (and ought to) there are several sets of ideological beliefs. Robinson and Bell (1978), e.g., find that in England the belief in a just society and in the United States the belief in monetary success dominates. Hasenfeld and Rafferty (1989), on the other hand, contend that in Western welfare states two contrasting sets of ideological beliefs are in competition with each other. On the one hand, there is the belief in the abundance of opportunity and in the virtue of individualistic achievement (Huber and Form, 1973; Kluegel and Smith, 1986) and on the other hand the belief in solidaristic sharing as a way to get a more equal and fair allocation of society's resources (Parkin, 1974; Shepelak, 1989). ${ }^{5}$

In this study we have chosen to explore the role of one of these sets, especially with a view to the development of an instrument which adequately measures the ideological stance of people. Hereto, we have taken the lead of Huber and Form and of Kluegel and Smith and have taken as a starting point the view that our society is characterized by the openness of its structure of abundant opportunities. To make such a structure work

\footnotetext{
${ }^{5}$ About the same contrasting sets of beliefs can be inferred from the study of Ritzman and Tomaskovic-Devey (1992) if their equity and equality distribution rules are considered as ideological beliefs. In view of the way they have measured these rules this seems to be the case; at least they differ in level of generality and abstraction considerably from the justice principles we discern in this study.
} 
people have to be as free as possible and government has to intervene as little as possible. We have here the ideology based on Adam Smith's hidden hand and we refer to it as the free market ideology. The outcome of this structure of opportunities, i.e., the allocation of income, is the responsibility of individuals and thus depends on their efforts. It is only logical that those who adhere to this ideology tend to favor allocation of income on grounds of merit and that those who disagree tend to be in favor of need considerations.

With regard to income, we predict that the higher the income the higher the adherence to the free market ideology and the lower the income the lower this adherence will be. We also predict that the better one's class position the more one will adhere to the free market ideology and the worse this position is the lower this adherence will be. Finally, we predict that the more one adheres to the free market ideology the more one will prefer the merit principle and the less one adheres to the free market ideology the more one will prefer the need principle (for the predictions with respect to the other variables see below).

\section{Enlightenment Thesis}

This thesis is formulated by Robinson and Bell (1978). In their research they assume that through education people become more familiar with the major values and themes of Western Civilization upon which the Enlightenment has left a heavy mark. As they put it: "The history of democratic revolutions-and evolutions-implies equality in a variety of ways, remains a charter myth of these societies, and is taught the young as sacred past" (p. 128). This led them to suppose that the higher educated will be more in favor of equality than the lower educated. They find confirmation for this assumption in England but not in the United States. If this research finding is valid, it means in our case that the more education people have the less they will prefer the free market ideology and the merit principle of justice and the more they will be in favor of the need principle.

\section{Historical Shift Thesis}

Robinson and Bell (1978) also assume that there has been a historical shift toward an egalitarian Zeitgeist. They derive this assumption from a paper by Beteille on the decline of social inequality and substantiate it with instances from England and the United States indicating such a decline. Accordingly, Robinson and Bell predict that younger people are more in support of equality. In their study, their hypothesis was supported by the 
data in the United States, but not in England. In our case this thesis predicts that the younger people are the more they will disagree with the free market ideology and the related merit principle and the more they will prefer the need principle of justice.

\section{Gender Thesis}

According to some research findings men and women are assumed to differ with respect to the ethic they use when judging justice questions (Gilligan, 1982). Men use an "ethic of justice" which leans more to the free market ideology and the merit principle and women use an "ethic of care" which is less in agreement with the this ideology and more in accordance with the need principle of justice.

\section{Distributive Justice: The Conceptual Model}

In the foregoing we elaborated five theses that state the relationships between class, income, education, age, and gender-the independent variables-on the one hand and the preferences for the merit and need principles of justice - the dependent variables - on the other. We have also gone into the role that ideology, the free market ideology in our case, may play in this set of relationships. We came to the conclusion that the free market ideology is to be expected to affect the preference for one of the two justice principles and is probably at its turn affected by the independent variables.

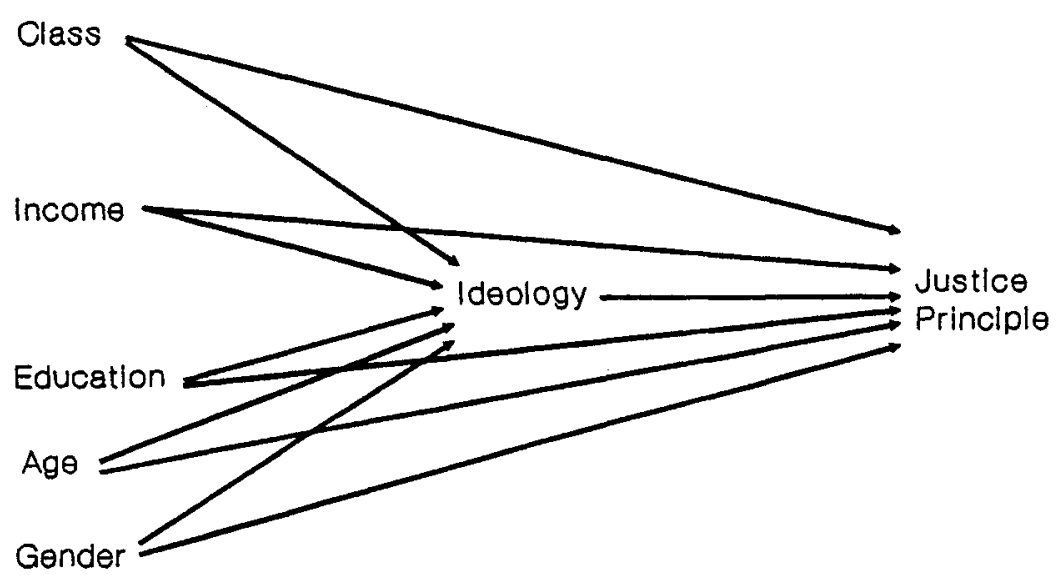

Fig. 2. Conceptual model. 
This means it functions in the conceptual model as an intermediate variable. In Fig. 2 we depict the relationship mentioned above in the form of a conceptual model which use as the theoretical model for our path analysis.

\section{METHOD}

\section{Data}

Data for this study come from a larger study into The Conditions for a Municipal Policy of Societal Renewal (Bons, 1992) conducted in 1991 by graduate students in sociology as part of a research training program. The survey was designed by the staff of the program (of which the second and the third author were members) who also executed the sampling procedure. The data were gathered in a survey in which the respondents were selected by means of a random-digit dialing procedure from the greater Rotterdam area, a metropolitan area. ${ }^{6}$ This procedure resulted in a probability sample of 461 respondents of which 316 respondents were interviewed. 145 respondents $(31 \%)$ could not be reached at their home or refused to participate.

We have restricted the sample for analysis in this study to respondents who are currently employed or who are receiving a social security benefit. This is a consequence of the way in which the class variable in this study is conceptualized and operationalized (see also below). We have, therefore, excluded the following categories from the original sample: (i) housewives (61) because they do not occupy a position in the class scheme we used in this study (see below); (ii) full-time students (25) who receive a governmental grant; and (iii) pensioners (60) over 65 . In the Netherlands their income consists (wholly or partly) of a special governmental retirement benefit (A.O.W.). Although both students and pensioners receive some kind of social security benefit, their situation is not comparable to the situation of those who are forced out of the work force because of lack of jobs or illness. This resulted in a sample of 170 respondents of which 138 were with and 32 without a job.

\footnotetext{
${ }^{6}$ This area consists of Rotterdam, Schiedam, Vlaardingen, Hoek of Holland, and Capelle a/d IJssel which are part of the same telephone district. The random generation of the telephone numbers which all begin with a 4 and consist of seven digits was based on a specially developed random number generating computer program. This program was devised by another member of the staff, J. Braster.
} 


\section{Measures}

In the survey the respondents were asked which criterion they preferred regarding the allocation of income. The interview also contained questions about occupation, ideology, and background variables such as age, sex, education, and income. The measures used in this study are presented below.

\section{Class Position}

We mentioned before that class can be measured in several ways. On theoretical grounds we prefer a measurement along Weberian lines but we find Weber's class concept too indefinite for fruitful use in research. One of the best-known elaborations of this class concept is the one by Goldthorpe (1980) which is, according to Marshall et al. (1988), on theoretical, methodological, and empirical grounds to be preferred to otherrival-conceptualizations of class. We therefore-with a slight modification-use Goldthorpe's conceptualization.

Goldthorpe's premise is the same as Weber's, viz., people differ with regard to the possibilities they have in securing their life chances on the market. Goldthorpe discerns the following differences: the source and level of income, security of employment, chances on promotion, location within systems of authority and control, and degree of autonomy in performing the work tasks.

On the basis of these differences Goldthorpe arrives at seven classes. We use his classification which we complement with an eighth category, the class of social security recipients. Goldthorpe and Payne (1986) did the same. They added a comparable category at the bottom of the Goldthorpe seven-class scheme, viz., the category of the unemployed, a class category which in their view contains positions lower than working-class positions. This gives us the following classification scheme:

I. Higher-grade professionals, administrators, and officials; managers in large establishments; large proprietors. These occupations give high and secure incomes, prospect of promotion, authority, control and autonomy.

II. Lower grade professionals, administrators, and officials, higher-grade technicians; managers in small establishments; supervisors of nonmanual employees. These occupations score lower-but still relatively high-on the above-mentioned criteria than the Class I occupations.

III. Routine nonmanual employees in administration and commerce and personal service workers. The so-called routine white collar workers. These occupations are relatively low in income, but relatively secure, and offer some chances of promotion. They derive some status from the association with the Class I and II occupations. They are, however, low in authority, control and autonomy.

IV. Small proprietors, artisans, farmers, fishermen, etc. Together these categories 


\begin{abstract}
form the petit bourgeoisie. The market situation, i.e., income and economic security, of these occupations is variable and may easily change due to economic circumstances. At the same time, however, people in this class have a high degree of autonomy.

V. Lower-grade technicians; supervisors of manual workers. The "blue-collar elite." Their incomes are relatively high and secure and their chances of promotion limited. They have some degree of authority, control and autonomy although this is restricted by the supervision exercised by people in higher hierarchical positions.

VI. Skilled manual workers. They have higher incomes than Class VII workers but few chances of promotion, and not much authority, control, and autonomy.

VII. Semiskilled and unskilled manual workers; agricultural workers. These occupations score the lowest on all criteria of all the occupations in society.

VIII. Social security recipients. They generally have a low income which proves to be insecure due to government policies of budget cuts and they have few prospects of escaping from their marginal position.
\end{abstract}

Goldthorpe's scheme is adopted to the Dutch situation by Ganzeboom et al. (1987) and requires information on the occupation of the respondent and on his or her employment status: i.e., self-employed (and in that case how many employees); wage earning (and in that case how many subordinates); or social security benefit recipient (and in that case what kind of benefit). Table I gives the distribution of the respondents across the eight class categories.

The use of Goldthorpe's class scheme poses an important problem for our predictions regarding the effect of class on the principles of distributive justice and ideology. These predictions assume some kind of hierarchy in the distribution of life chances. Goldthorpe (1980), however, made clear that his "class schema should not be regarded as having a consistently hierarchical form" (p. 42) mainly because the life chances of the members of the Classes III, IV, and V are difficult to compare with each other. On the other hand, he shows that there is a hierarchy in the distribution of life chances running from "good" to "poor" if classes are taken together, e.g., class positions I and II are comparable in terms of life

Table I. Frequency of Respondents by Class Position

\begin{tabular}{clcr}
\hline $\begin{array}{c}\text { Class } \\
\text { position }\end{array}$ & \multicolumn{1}{c}{ Occupational title } & $\begin{array}{c}\text { No. of } \\
\text { incumbents }\end{array}$ & $\%$ \\
\hline I & Managing/administrative elite & 23 & 14 \\
II & Middle management/supervisors & 41 & 24 \\
III & Routine white collar & 27 & 16 \\
IV & Small proprietors & 9 & 5 \\
V & Supervisors manual & 7 & 4 \\
VI & Skilled manual & 15 & 9 \\
VII & Semi- \& unskilled manual & 16 & 9 \\
VIII & Social security recipients & 32 & 19 \\
Total & & 170 & 100 \\
\hline
\end{tabular}


chances-relatively good-and the same applies for class positions VI and VII whose chances are relatively poor.

Following Goldthorpe's lead, we have put the eight classes in a more global hierarchical order and are thus able to formulate our predictions more precisely. ${ }^{7}$ Respondents in Class I and II will be most in favor of the merit principle and the free market ideology and less in favor of the need principle; conversely, the respondents in Class VIII will favor the need principle most. They are less in favor of the merit principle and the free market ideology. The incumbents of class positions III, IV, and V, on the one hand, and those of class positions VI and VII, on the other, will show preferences that lie between these extremes. More precisely, respondents in Class III, IV, V will show preferences that resemble more those of Class I and II respondents, while respondents in Class VI and VII will show preferences that resemble those of Class VIII.

Income. This independent positional variable is operationalized as net income in Dutch guilders per month. It is measured in intervals of 200 guilders.

Education. The third independent variable is operationalized as the level of education. In the Dutch situation, this means that each level of education represents the number of years a respondent has spent in the educational system. The variable was measured as follows: elementary school not finished, score 1; elementary school, 2; lower vocational education, 3; secondary school (lower level), 4; secondary school (higher level), 5 ; intermediate vocational education, 6 ; higher vocational education, 7 ; and university, 8.

Age is operationalized as the year of birth and recorded so that the older the respondent is, the higher the score.

Gender is operationalized as a dummy variable in which female $=$ score 1.

\footnotetext{
${ }^{7}$ There is also a methodological problem arising from the fact that the classes do not form an explicit hierarchy. It is now impossible to simply use one variable "class position" in the analysis. We, therefore, use dummy variables. The dummies represent seven of the eight categories of class; Class I is omitted and serves as the reference category. In the path analysis the dummy variables are replaced by a quantitative variable which is the linear combination of the dummies representing class position. We follow here the procedure as described by Rossi and Anderson (1982, p. 64). In this procedure, also called "coding proportional to effect," the mean of the deleted class category becomes the constant and every other category receives the scale value of $b_{0}+b_{k} X_{k}\left(b_{k}=\right.$ the partial regression coefficient attached to each of the $\mathrm{k}$ categories). The explained variance $\left(R^{2}\right)$ of the combined variable remains the same as that of the dummy variables. The raw regression coefficient becomes 1.00 and the beta coefficient of the combined variable is used to measure the proportion of the variation in the dependent variable accounted for by all class categories. This way the effect of class is comparable to the effects of the other variables in the analysis. The sign of the beta coefficient has no substantive meaning as it is positive by definition.
} 
Ideology. Free market ideology is seen as an intermediate variable in the conceptual model. This variable is designed as a scale. As we did not have an example of such a scale we had to devise a scale ourselves. The scale we use here is therefore a provisional one. We have used 4 Likert-type statements to measure this variable. ${ }^{8}$ These items were summed to form a scale, which was not entirely satisfactory, with a Cronbach's alpha of 0.58 .

Justice Principle. This variable is conceptualized as the dimension underlying allocation criteria. These criteria are operationalized in 12 Likerttype questions each representing either a merit or a need criterion. Nine of these questions concerned the criteria people prefer regarding the allocation of income and the 3 others concerned the sufficiency of welfare benefits. (See Appendix A for the questions.)

\section{RESULTS}

\section{Justice Principles}

We started this paper by asking whether people use principles of distributive justice regarding the allocation of income. We stated that we view justice principles as the dimensions underlying the criteria people consider relevant for the allocation of income. We measured these criteria by means of a questionnaire (Appendix A) with six merit and six need items. We excluded one of the merit items, responsibility, from the analysis because the responses on this item did not show enough variation, i.e., only two respondents disagreed with this statement. The other items were analyzed by means of factor analysis which resulted in a rotated varimax solution of four factors with an eigenvalue $>1.0$. On the basis of Cattell's scree test (1966) we decided to drop the fourth factor. This meant dropping one of the need items, viz., the family item, as this item loaded only on the fourth factor. The result is an extraction of three factors which explain $50 \%$ of the total variance in the items (see Table II in which factor loadings $<.30$ are omitted).

The first factor represents the need principle of justice and contains five of the six need items. These five items form a scale with a Cronbach's

\footnotetext{
${ }^{8}$ The statements were (1) It is very possible to rise to a higher position in the Netherlands. This is true for people from the lower classes of society as well; (2) Private enterprise should be obstructed as little as possible; (3) Bigger differences in income are necessary, because these motivate people to take on responsibility; (4) People should initially take care of themselves and not put all their problems in the hands of the government. The possible answers were: strongly agree; agree; neither agree, neither disagree; disagree; strongly disagree.
} 
Table II. Factor Analysis of Items Measuring Justice Preference (Varimax Rotation)

\begin{tabular}{lccc}
\hline \multicolumn{1}{c}{ Item } & Factor 1 & Factor 2 & Factor 3 \\
\hline Welfare benefit too low for a single person & 0.79 & - & - \\
Welfare benefit too low for a single mother & 0.67 & - & - \\
Welfare benefit too low for a couple & 0.78 & - & - \\
Having a job or being unemployed not relevant & & & - \\
for income & 0.56 & - & \\
Physically handicapped are entitled to more & 0.43 & - & - \\
income & - & 0.72 & - \\
Better results on the job, more income & - & 0.85 & - \\
More initiative, more income & - & 0.38 & 0.69 \\
More experience with the job, more income & - & 0.38 & 0.66 \\
More expertise/professional knowledge, more & - & - & 0.73 \\
income & 2.4 & 1.9 & 1.1 \\
Higher education, more income & .68 & .68 & 10.4 \\
Eigenvalue & & .53 \\
Variance explained & & &
\end{tabular}

alpha of .68 which we consider satisfactory. The principle centers on the notion that people at the very least need enough income to live on. The emphasis lies on the welfare questions and the notion that one's employment status should not determine one's right to income. The need principle we found corresponds to Boulding's principle of disalienation (Kluegel and Smith, 1981).

The second factor we have found can be seen as the merit principle of justice. It consists of four of the six merit items. These items form a scale (Cronbach's $\alpha .68$ ). The principle reflects the preference for rewarding differences which are related to job activities (see for a comparable result Gartrell, 1985). Bouckaert (1990) is right in stating that the relation between the effort put in and the result of performing one's job forms the kernel of the merit conception.

The third factor we have found indicates that there might be another merit principle. The education item loads on this factor as do experience and expertise. These last items load, however, on the second factor as well. The three items form a relatively weak scale with a Cronbach's alpha of .53. This is considerably lower than the alpha for the four items of the second factor and warrants maintaining the second factor as the merit principle and dropping the third from the analysis.

Still, the education item, as an important item in this third factor, suggests that there is reason to assume that this factor might reflect a 
preference for rewarding more general kinds of investments. Education is probably the most outstanding example of these kinds of investments. The fact that experience and expertise load on this factor as well supports the idea of a second merit principle. Accepting a second merit principle would, moreover, correspond with the distinction Hochschild (1981) made regarding her norms (principles in our terminology) of distributive justice. She distinguished alongside ascription and strict equality-both of which fall outside our study-need, investments, and results as norms or principles of justice. The way she described "results" concurs with the four items in our first merit principle and her "investments" norm-conceived as a differentiation norm-has like the suggested second merit principle education at its core.

The conclusions that there might be more than one merit or contribution principle of distributive justice-each reflecting different kinds of contributions-also corresponds to the contention of Tornblom (1992) that there are several contribution principles (subrules in his terminology). At this point, we can do no more than conclude that people might use three different principles of distributive justice regarding the allocation of income: the first reflecting allocation according to needs-the need principle of distributive justice; the second according to efforts-the merit principle; and the third according to investments. This last principle reflects different kinds of contributions and could be depicted as the "achievement" principle. The suggestion of the existence of such a principle is reason enough to include more (and probably more precisely formulated) items regarding these kinds of general investments in future research.

\section{The Theses}

The first step in the analysis of the theses is to look for consensus. We added up the scores on the items, respectively, forming the need and the merit principle. The lowest possible aggregate score on the five need items (i.e., strongly agree with each of them) is 5 and the highest (i.e., strongly disagree) 25 . The actual mean score is 13.6 -well above the theoretical mean of 12.5 -with a standard deviation of 2.7 . The possible aggregate scores for the four merit items range from 4 to 20 . The mean score is 9.1 (theoretical mean 10) and the standard deviation 2.7. The actual mean scores compared with the theoretical ones show that the preference for the merit principle is relatively high and for the need principle of justice less high but still considerable. This corresponds with the results of Dutch research into distributive justice (Berting et al., 1986; Hermkens and Van Wijngaarden, 1989; Steijn and De Witte, 1992) and with that of American 
research on the same topic (see e.g., the compilation by Kluegel and Smith, 1981). Both standard deviations, however, point out that alongside the relatively widespread adherence to both principles of distributive justice there is a considerable variation in this adherence. This shows that the consensus is not generally held.

We have stated five explanations in the form of theses regarding the variations in consensus and assumed a set of variables that could (partly) account for these variations. These variables are class, income, free market ideology, education, age, and gender. The theses are first investigated by means of a path analysis in which these variables and the principles of justice are included. Thereafter each of the theses is examined more specifically. Finally, we review social position, ideology, and justice principles as the main factors in our study more closely.

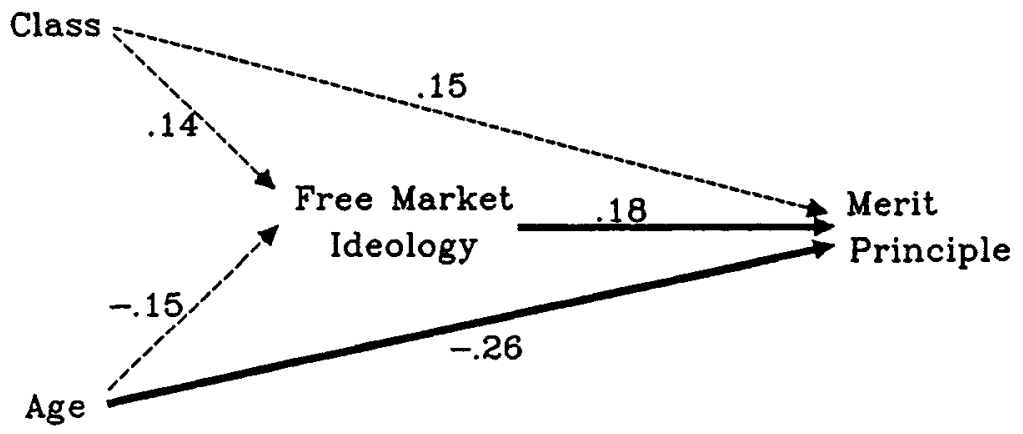

Fig. 3. Path model merit principle of justice.

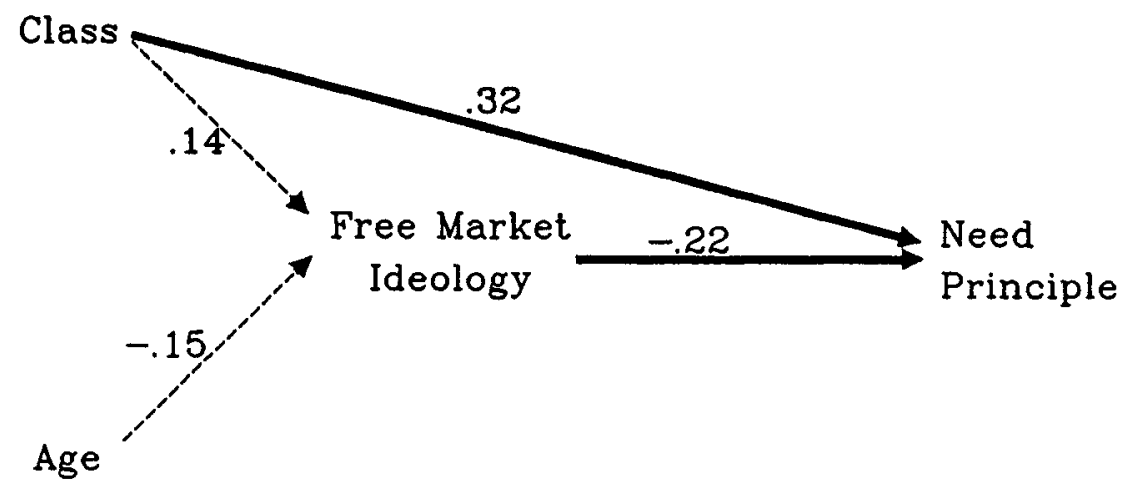

Fig. 4. Path model need principle of justice. 


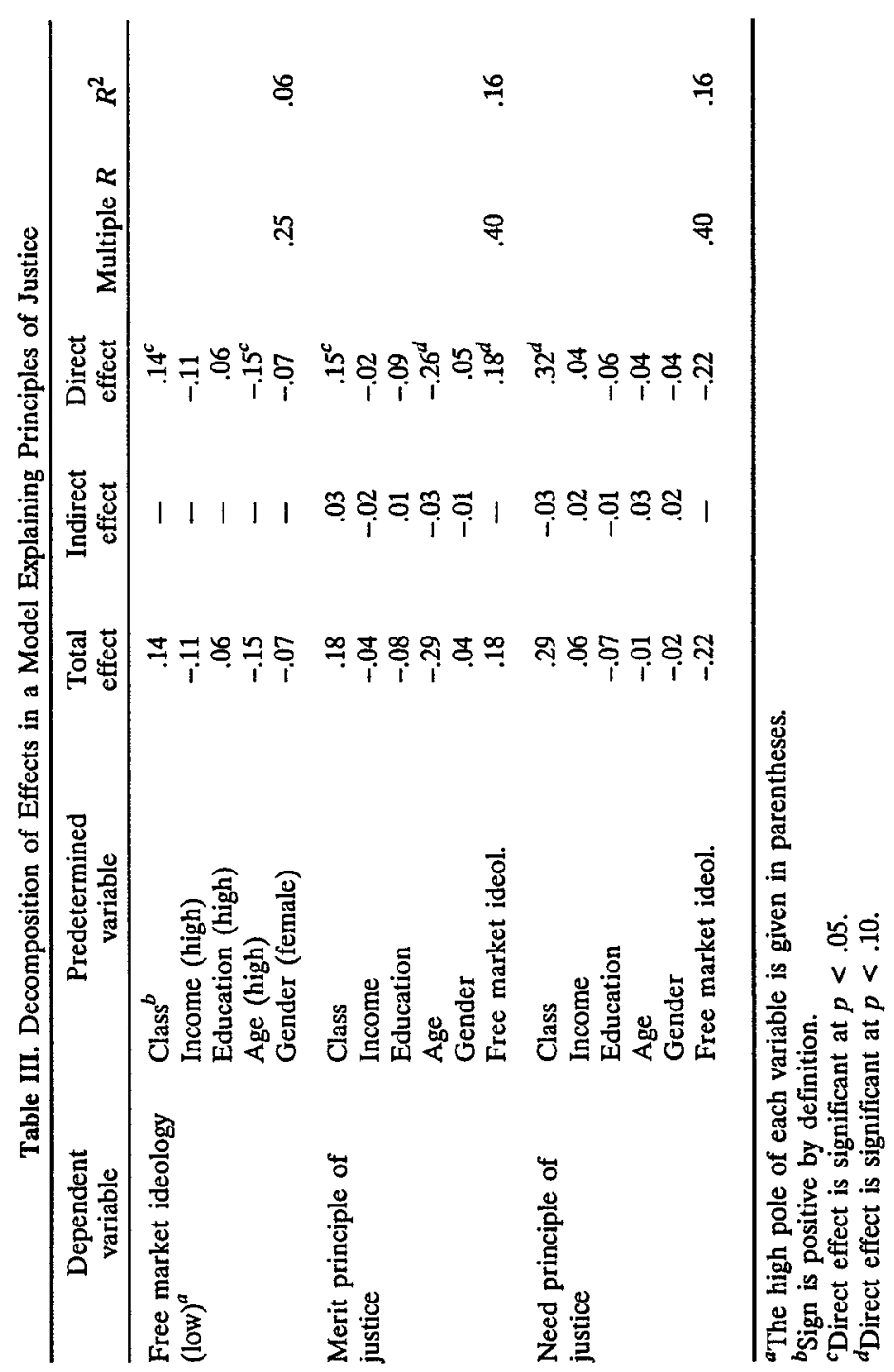




\section{The Path Analysis}

The descriptive statistics for the variables in the path analysis and the intercorrelations among them are given in Table B1 (appendix B). The effects of the independent variables on the intermediate ones and the effects of both the independent and the intermediate variables on the dependent ones are given in Table III. Figures 3 and 4 present the path models regarding the merit and the need principle of justice, respectively. In this analysis we use two levels of significance, viz., $5 \%$ (the solid lines in Figs. 3 and 4) and 10\% (the dotted lines). In view of our limited sample compared to the much larger samples in most of the studies we refer to, a higher level than the customary 5\% level seems to us to be warranted.

When we look at the merit path model (Fig. 3) we see that the variables collectively explain $16 \%$ of the variance in the preference of respondents for the merit principle of justice. The ideological variable, i.e., the free market ideology, mediates the effect of class position and of age on the dependent variable, the merit principle.

The explained variance in the second path model (Fig. 4) is the same, viz., $16 \%$. The ideological variable is related to the need principle in a way which we expected, i.e., adherence to the free market ideology is negatively related to this justice principle. Ideology mediates the influence of class and age on the need principle. Class also has a direct effect on the need principle of justice; age does not have such an effect.

The other independent variables income, education, and gender do not have a statistically significant effect on either the ideology variables or the justice principles.

\section{The Self-Interest Thesis}

This thesis predicts a relationship between class and income, on the one hand, and the merit and need principle, on the other. Figures 3 and 4 show that class is directly related to both principles while income is not. This finding suggests that class is a better indicator of social position in relation to allocation preferences and related attitudes than income. The same may be inferred from Table B1 (Appendix B). The zero-order correlations between income and both justice principles, which are all statistically significant and in the expected direction, disappear when controlled for class and the other variables in the analysis.

As we have stated before, the sign of the path coefficient of class does not have a meaning of its own and thus does not show whether the rela- 
tionship between class and both principles of justice are as expected. To see whether this is the case we have looked into the unstandardized regression coefficients of the dummy variables and have executed a bivariate analysis. The results in Tables B2 and B3 (Appendix B) show a confusing pattern. All cases agree-as expected-less with the merit principle of justice than Class I. The opposite is found with the need principle. Here all classes (Class $\mathrm{V}$ and somewhat Class II expected) agree more than Class I with principle which is as we predicted. In both cases, however, the expected pattern holds true only for the opposite position of Class I (and in a certain degree also Class II) and Class VIII. The preferences of these classes fit in with their interests. The preferences of the other classes does not follow the predicted sequences, i.e., it is not consistently so that the preferences of the incumbents of Class III, IV, and V resemble those of Class I and II and that those of Class VI and VII resemble those of Class VIII.

\section{The Ideology Thesis}

This thesis predicts first a relationship between social position-class and income-and the free market ideology. As was the case with the justice principles, the prediction holds for class but not for income. When we look at the unstandardized regression coefficients of the dummy variables and at the results of the bivariate analysis, we find a pattern that is even more confusing. All classes-Class VII excepted-agree less than incumbents of Class position I with the free market ideology, as was predicted. There is again the polarity of Class I and Class VIII but the pattern is now less clearly marked. The preferences of the incumbents of the other class positions do not follow the predicted pattern. The deviation of Class VII - the lower manual workers-is especially notable in this respect.

The second prediction concerns the relationship between ideology and the justice principles. As expected, the free market ideology is positively related to the merit principle and negatively related to the need principle, although the explained variance is rather small. Ideology connects-also as expected-a social structural variable like class with the preference for the two principles of justice. The precise relationship between class, ideology and the justice principles is, however, rather vague.

\section{The Enlightenment Thesis}

This thesis proposed by Robinson and Bell (1978) predicts that those with higher education would be less in favor of the free market ideology and the merit principle and more in favor of the need principle. As can 
be inferred from the foregoing path analysis, our results do not confirm this thesis. In this respect, the result fits in with the study of Robinson and Bell who got the same result for the United States.

\section{The Historical Shift Thesis}

Although, age is not related to the need principle of justice-which is contrary to the prediction of this thesis-it is (negatively) related to the free market ideology and the merit principle of justice. This (partially) confirms the predictions of the thesis which means that the older one is the more one adheres to this ideology and the more one prefers this principle. The result supports the idea that there is a shift over time in the direction of more support of equality. Kluegel and Smith, however, point to an alternative explanation, viz., that the preferences of people may change when they grow older. They find the same relationship and explain it as an effect of growing older. Older people appear to "attach more importance to individualistic factors as causes of poverty and wealth and [to] emphasize individual equity over equality or need as a basis for a just distribution of rewards" (1986, p. 288). Their explanation is, moreover, supported by the fact that the predicted relationship between age and the need principle is not present.

\section{The Gender Thesis}

Our results indicate no relationship between gender, ideology, and both principles of justice. This means that Gilligan's (1982) thesis regarding the affinity of women for an "ethic of care" does not seem to hold for women with an income of their own. Their beliefs regarding the structure of opportunities as well as their preferences for rewarding contributions and for compensating disabilities do not differ from those of men in the same situation. Whether there is a split between "earning" women and "nonearning" women with regard to these beliefs and preferences and whether Gilligan's thesis has to be qualified accordingly are questions that await further research.

\section{Again, Social Position, Ideology, and Justice Principles}

When we look more closely at class as the indicator of social position, free market ideology, and both justice principles and their interrelations, four results catch the eye. 
First, we found that our prediction regarding the relationship between class, ideology, and the justice principles is valid only for the incumbents of Class I and Class VIII positions whose preferences are clearly opposed to each other. When we look into the zero-order correlations (Table B1, Appendix B) we see that the incumbents of Class I and VIII positions differ in other respects, as well. Class I position holders have in significantly more cases a higher education and a higher income than Class VIII respondents. The same difference can be seen in regard to descent. Class I position holders have clearly in more cases a Class I and not a Class VII father (41 vs. 3\%). In the case of Class VIII respondents on the other hand there is a far greater chance that their father is a member of the working class, i.e.,, Class VII, than of Class I ( 42 vs. $9 \%$ ). This suggests that there is a rather big difference between the Class I and Class VIII positions, reflected among other things in the ideology to which the incumbents of those positions adhere and in the preference for a particular principle of justice.

The self-interest thesis we put forward is less general than we expected. It may be renamed the "underdog" thesis following Robinson and Bell who have put the underdog principle forward in their pioneering paper. The incumbents of Class VIII positions, especially, are the new underdogs who least agree with the dominant ideas about society and the just allocation of income. The dissent of the social security recipients in this respect is striking. In the words of Robinson and Bell: They do not accept the invitation of the dominant ideology "to accept and condone existing inequality as generally just and reasonable" (1978, p. 141); a result which concurs with the study of Kluegel and Smith who found that respondents "at the top and the bottom of the stratification order" differ in the support they gave to the dominant ideology $(1986$, p. 295). The study of Ritzman and Tomaskovic-Devey (1992), moreover, strongly suggests that this difference between top and bottom is even more pronounced regarding the contrasting set of beliefs-egalitarianism-which we did not include in our study. Such a variable needs a place in further studies into distributive justice.

Second, the confusing pattern regarding the preferences of the incumbents of the other class positions demands further explanation. Table B1 (Appendix B) shows that the incumbents of class positions II to VII differ less markedly from each other in respect of education, income, and descent. The effect of these differences can be seen in the diversity of the ideological positions of these classes. It is also reflected in their preferences for the merit and the need principles of justice. The confusing results indicate, moreover, that suggestions in the literature about a fragmentation of the class structure seem to be warranted (Roberts et al., 1977; Steijn and De Witte, 1994). A consequence of this fragmentation is that the pre- 
cise distribution of assets is no longer clear and it is therefore difficult to discern the different "intermediate," i.e., the former middle and lower class, class positions from each other. This is a problem for social scientists whose instrument-the class scheme-does not correspond any longer precisely enough with the diversity of the class positions in society. It could also be a problem for the people concerned for whom the ongoing fragmentation process may make it difficult to recognize their interests.

Third, ideology connects class as a social structure variable with preferences for the justice principles. This confirms the findings of Robinson and Bell (1978), Shepelak (1989), and Hasenfeld and Rafferty (1989). The way we have operationalized the ideological variable as free market ideology seems promising, but more work has to be done to arrive at a satisfactory measure of this ideology. As most of the variance of ideology remains unaccounted for, it seems necessary to take other beliefs into account, e.g., those concerning egalitarianism and fair sharing, and to look for other independent variables as well.

Finally, we notice that the ideology of the free market is clearly dominant in society. It is an ideology for which there is-just as Kluegel \& Smith (1986) assessed-widespread support (see also Ritzman and TomaskovicDevey, 1992). The overall mean score and the mean scores of each class lie well below the theoretical mean score of 12.0 on this variable (a low score means agree; see Table B3, Appendix B). As the effect of self-interest seems to be limited-as the relatively weak effect of class position on free market ideology shows-it is probable that socialization, especially through the media, plays an important role in producing and maintaining the dominance of this ideology. ${ }^{9}$ Especially in the 1980 s, the message of the superiority of the free market, the virtue of individualistic achievement, and the belief in the abundance of opportunity the market brings with, it has-explicitly and implicitly-been broadcast by television and radio and printed in newspapers and magazines. As the results of the study of Allen and Kuo (1991) suggest, exposure to these media may well affect the kinds of beliefs, opinions, and preferences we study.

\section{DISCUSSION}

This paper addresses two questions. The first asks whether people use principles of justice regarding the allocation of income. Our analysis

${ }^{9}$ The basic social-psychological processes which according to Kluegel and Smith (1986) may be important determinants of this ideology are not included in this study so that nothing can be said about the importance of these processes. 
confirms our theoretical expectation that at least two of these principles can be discerned, viz., a merit and a need principle of distributive justice. The merit principle reflects the preference for rewarding differences that are related to job activities, especially the effort put in and the results of performing one's job. The need principle, on the other hand, reflects the view that people need enough money to live on. This result means that the widespread use of both notions of justice in the literature on distributive justice is empirically warranted. Our empirical material indicates that there might be two merit principles (or subprinciples), i.e., one that prefers allocation based on contributions according to effort and result and one that prefers allocation based on contributions according to investment. As this second merit principle is only weakly represented in our data, more research is needed to find out whether people actually use these two different merit principles.

Although the adherence to both the merit and the need principle is widespread, there is also a considerable variation in this adherence. A consensus is this lacking. Our second research questions deals with the explanations for this lack of consensus. A multivariate analysis shows that out of five different theses suggested in the literature that could explain these differences, three were (partly) confirmed by the data.

The first thesis-self-interest-predicts that both income and class affect the adherence to the merit and the need principle of justice. This prediction, however, only holds for class, as there is no relation between income and the preference for the two principles. Moreover, the precise relationship between class and justice principles differs from what we expected. In fact, there is only a clear marked difference in adherence between the incumbents of the highest and of the lowest class positions, i.e., between higher management (who are more in favor of the merit and less in favor of the need principle) and the social security recipients (who are, conversely, less in favor of the merit and more in favor of the need principle). The preferences of the incumbents of the other class positions are not in line with our predictions and, all in all, the data regarding these preferences reflect a confusing pattern.

The second thesis-ideology-is also supported by our results. This thesis is a refinement of the self-interest thesis as ideology mediates in part the effect of class on justice principles. We found, however, that the way the self-interest and the ideology theses are formulated is problematic because the predictions regarding the relationship between class, ideology and justice principles are only really confirmed with respect to the incumbents of Class I and Class VIII positions. As stated above, this situation concurs more with the underdog principle of Robinson and Bell (1978). Further research is needed, particularly with respect to more precise measurements 
of social position and to extension of ways of measuring the ideology variables.

The third thesis-historical shift-is partially supported by our data. Older people show more preference for the free market ideology and the merit principle of justice than younger people. At this point, further research is needed to find out whether this represents only the effect of growing older or is a genuine historical shift.

Finally, we found no support for the enlightenment and for the gender theses; the more educated do not differ from the lower educated in their adherence to the free market ideology and the two justice principles, neither did men and women. Although, three out of five theses are partially supported by the data, the total effect (in terms of explained variance) of our independent and intermediate variables on the dependent variables is limited. This suggests that we have to look at other variables, such as the functioning of media or the activities of left-wing political parties, which may help to explain the support for specific ideologies and justice principles.

\section{ACKNOWLEDGMENTS}

We thank Piet Hermkens, Dick Houtman, Jan Koster, and the anonymous reviewers for their thorough and helpful comments and Brigitte d'Anjou and Michael Krass for their efforts to transform the text into English.

\section{APPENDIX A}

\section{Questions Concerning the Criteria People Prefer in Allocating Income ${ }^{\mathrm{A} 1}$}

I would like to discuss with you the allocation of income in the Netherlands. As you know, one's income depends on a large number of things, such as the level of pay or social security benefit, children's allowance, rent subsidies, etc. [Interviewer shows card] On this card you will find a number of things which affect the level of income. I would like to learn from you-based on the statements formulated on this card-which things, according to you, ought to have an effect on one's income. The possible

${ }^{A l}$ Questions 64, 65, 67, 69, 71, and 72 concern merit criteria and questions $66,68,70,73,74$, and 75 need criteria. 
answers are strongly agree; agree; neither agree; neither disagree; disagree; strongly disagree.

64. A person with a higher education than another person should receive a higher income.

65. A person who obtains better results in his job than another person should receive a higher income.

66. It should not really matter for one's income whether one is employed or unemployed. Your expenditures remain about the same anyway.

67. A person who shows initiative should have a higher income than a person who does not do more at his job than is required.

68. A person with a physical handicap which gives him higher financial burdens than others have should receive a higher income.

69. A person who has a job that carries with it more responsibility, should receive a higher income.

70. The household situation (having small children, having a partner with a job) ough not to have effect on the level of income.

71. A person who is more experienced in his job should receive a higher income than someone with less experience.

72. A person who has much expertise or professional knowledge at his disposal should receive a higher income than someone who has less of such expertise or knowledge at his disposal.

I would like to know now what your opinion is regarding the level of the benefit people receive when they are on welfare. The possible answers are that the amount should be much higher; should be higher; is about right; ought to be lower; ought to be much lower.

73. The welfare benefit for a single person is $f 1.148,03^{\mathrm{A} 2}$ net a month at the moment. What do you think of that amount?

74. The welfare benefit for a single mother with one child is $f$ $1.476,04$ net a month at the moment. What do you think of that amount?

75. The welfare benefit for a married couple without children is $f$ $1.640,04$ net a month at the moment. What do you think of that amount? 


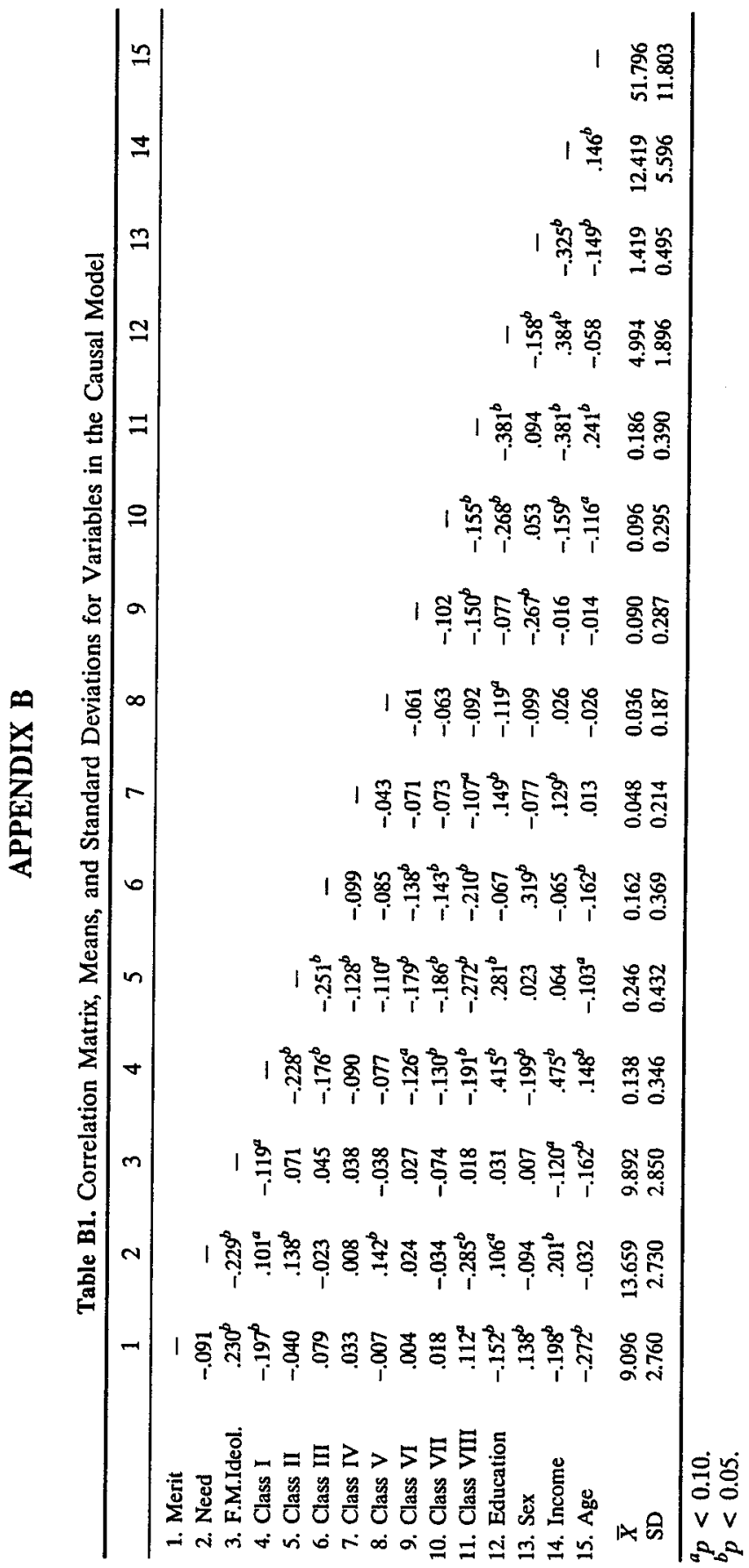


Table B2. Regression Results of Dummy Variables of Class Position on Merit Principle/Need Principle/Free Market Ideology ${ }^{a}$

\begin{tabular}{|c|c|c|c|c|c|c|}
\hline \multirow[b]{2}{*}{ Class } & \multicolumn{2}{|c|}{ Merit principle } & \multicolumn{2}{|c|}{ Need principle } & \multicolumn{2}{|c|}{$\begin{array}{c}\text { Free market } \\
\text { ideology }\end{array}$} \\
\hline & $B / S E$ & $t$ & $B / \mathrm{SE}$ & $t$ & $B / \mathrm{SE}$ & $t$ \\
\hline II & $0.284 / 0.754$ & 0.377 & $0.251 / 0.743$ & 0.337 & $0.812 / 0.814$ & 0.999 \\
\hline III & $0.568 / 0.898$ & 0.632 & $-0.586 / 0.886$ & -0.661 & $0.827 / 0.971$ & 0.852 \\
\hline IV & $1.156 / 1.093$ & 1.057 & $-0.326 / 1.080$ & -0.302 & $1.092 / 1.183$ & 0.923 \\
\hline V & $0.377 / 1.311$ & 0.288 & $0.847 / 1.222$ & 0.694 & $0.018 / 1.342$ & 0.013 \\
\hline VI & $0.567 / 1.003$ & 0.565 & $-0.417 / 0.990$ & -0.421 & $0.657 / 1.086$ & 0.604 \\
\hline VII & $0.290 / 1.075$ & 0.270 & $-1.069 / 1.060$ & -1.008 & $-0.211 / 1.164$ & -0.181 \\
\hline VIII & $1.183 / 1.001$ & 1.181 & $-2.123 / 0.988$ & -2.149 & $0.780 / 1.082$ & 0.721 \\
\hline
\end{tabular}

${ }^{a}$ Class I omitted. Coefficient significant if twice its standard error.

Table B3. Mean Scores on Ideology by Class Position

\begin{tabular}{cccc}
\hline Class position & $\bar{x}$ Merit & $\bar{x}$ Need & $\bar{x}$ Free market \\
\hline I & 7.7 & 14.3 & 9.0 \\
II & 8.9 & 14.3 & 10.2 \\
III & 9.6 & 13.5 & 10.2 \\
IV & 8.9 & 14.2 & 9.9 \\
V & 9.0 & 15.4 & 9.1 \\
VI & 9.1 & 13.9 & 10.1 \\
VII & 9.3 & 13.4 & 9.3 \\
VIII & 9.7 & 12.0 & 10.0 \\
Total & 9.1 & 13.7 & 9.9 \\
$p$ & $>0.30$ & $<0.01$ & $>0.70$ \\
Eta $^{2}$ & .05 & .11 & .03 \\
\hline
\end{tabular}

\section{REFERENCES}

Allen, R. L., and Kuo, C. (1991). Communication and beliefs about racial equality. Discourse Soc. 2: 259-279.

Alves, W. M., and Rossi, P. H. (1978). Who should get what? Fairness judgments or the distribution of earnings. Am. J. Sociol. 84: 541-564.

Alwin, D. F. (1987). Distributive justice and satisfaction with material well-being. Am. Sociol. Rev. 52: 83-95.

Bell, J., and Schokkaert, E. (1992). Interdisciplinary theory and research on justice. In Scherer, K. R. (ed.), Justice: Interdisciplinary Perspectives, Cambridge University Press, Cambridge, U.K., pp. 237-254. 
Berger, J., Zelditch Jr., M., Anderson, B., and Cohen, B. P. (1972). Structural aspects of distributive justice: A status value formulation. In Berger, J., Zelditch Jr., M., and Anderson, B. (eds.), Sociological Theories in Progress, Vol. 2, Houghton-Mifflin, New York, pp. 119-146.

Berting, J., Steijn, A. J., and De Witte, M. J. (1986). Rotterdammers Over Sociale Ongelikheid. Verslag van een Onderzoek Naar Rechtvaardigheidsoordelen, Maatshcappijbeelden en Beoordeling van Beroepsgroepen [People of Rotterdam on Social Inequality. A Study into Justice Judgments, Visions on Society and Judgment of Occupational Categories], Erasmus University, Rotterdam.

Bons, C. (1992). Het Draagvlak voor de Sociale Vemiewing in Rotterdam The Conditions for Societal Renewal in Rotterdam], Erasmus University, Rotterdam.

Bouckaert, L. (1990). Rechtvaardigheid: Opinies en morele intuities [Justice: Opinions and moral intuitions]. In Bouckaert, L., De Witte, H., Lagrou, L., Overlaet, B., and Schokkaert, E. (eds.), Wie Verdient Meer? Een Opinieonderzoek naar de Rechtvaardigheid van Inkomensverschillen [Who Earns More? An Opinion Study into the Justice of Income Differences], Acco, Leuven/Amersfoort, pp. 111-129.

Buchanan, A, and Mathieu, D. (1986). Philosophy and justice. In Cohen, R. L. (ed.), Justice: Views from the Social Sciences, Plenum Press, New York, pp. 11-45.

Cattell, R. B. (1966). The meaning and strategic use of factor analysis. In Cattell, R. B. (ed.), Handbook of Multivariate Experimental Psychology, Rand McNally, Chicago, pp. 174-243.

Cohen, R. L. (1986). Introduction. In Cohen, R. L. (ed.), Justice: Views from the Social Sciences, Plenum Press, New York, pp. 1-9.

Cohen, R. L., and Greenberg, J. (1982). The justice concept in social psychology. In Greenberg, J., and Cohen, R. L. (eds.), Equity and Justice in Social Behavior, Academic Press, New York, pp. 1-41.

Cook, K. S. (1975). Expectations, evaluations and equity. Am. Sociol. Rev. 40: 372-388.

Cook, K. S. (1987). Toward a more interdisciplinary research agenda: The potential contributions of sociology. Soc. Justice Res. 1: 5-18.

Cullen, B. (1992). Philosophical theories of justice. In Scherer, K. R. (ed.), Justice: Interdisciplinary Perspectives, Cambridge University Press, Cambridge, U.K, pp. 15-65.

Davis, H. H. (1979). Beyond Class Images, Croom Helm, London.

Deutsch, M. (1985). The Social Psychology of Justice, Yale University Press, New Haven, CT.

Drudy, S. (1991). The classification of social class in sociological research. Br. J. Sociol. 42: 21-41.

Evans, G. (1993). The decline of class divisions in Britain? Class and ideological preferences in the 1960s and the 1980s. Br. J. Sociol. 44: 449-471.

Ganzeboom, H., Luijkx, R., Dessens, J., De Graaf, P., De Graaf, N. D., Jansen, W., and Ultee, W. (1987). Intergenerationele klassenmobiliteit in Nederland Tussen 1970 en 1985 [Intergenerational class mobility in the Netherlands between 1970 and 1985]. Mens Maatschappij 62: 17-43.

Gartrell, C. D. (1985). Relational and Distributional Models of Collective Justice Sentiments. Soc. Forces 64: 64-83.

Gilligan, C. (1982). In a different voice: Psychological theory and women's development, Harvard University Press, Cambridge, MA.

Goldthorpe, J. H. (1980). Social Mobility and Class Structure in Modern Britain, Clarendon Press, Oxford.

Goldthorpe, J. H., Lockwood, D., Bechhofer, F., and Platt, J. (1969). The Affluent Worker in the Class Structure, Cambridge University Press, Cambridge, U.K.

Goldthorpe, J. H., and Payne, C. (1986). Trends in intergenerational class mobility in England and Wales, 1972-1983. Sociology 20: 531-555.

Graetz, B. (1986). Social structure and class consciousness: Facts, fictions and fantasies. Aust. N. Z. J. Sociol. 22: 46-64.

Grimes, M. D. (1989). Class and attitudes toward structural inequalities: An empirical comparison of key variables in neo- and post-Marxist scholarship. Sociol. Quart. 30: 441-463. 
Hamilton, V. L., and Rytina, S. (1980). Social Consensus on Norms of Justice: Should the Punishment Fit the Crime? Am. J. Sociol. 85: 1117-1144.

Hasenfeld, Y., and Rafferty, J. A. (1989). The determinants of public attitudes toward the welfare state. Soc. Forces 67: 1027-1048.

Hermkens, P. L. J., and Boerman, F. A. (1989). Consensus with respect to the fairness of incomes: differences between social groups. Soc. Res. 3: 201-215.

Hermkens, P. J. L., and Van Wijngaarden, P. J. (1989). Rechtvaardigingscriteria en Inkomensongelijkheid: Onderzoek uit 1976 Herhaald [Justification Criteria and Income Inequality: 1976 Study Replicated], Ministerie van Sociale Zaken, Den Haag, The Netherlands.

Hochschild, J. L. (1981). What's Fair; American Beliefs About Distributive Justice, Harvard University Press, Cambridge, MA.

Homans, G. C. (1961). Social Behaviour. Its Elementary Forms, Routledge \& Kegan Paul, London.

Homans, G. C. (1974). Social Behaviour. Its Elementary Forms (rev. ed.), Harcourt, Brace \& Jovanovich, New York

Homans, G. C. (1982). Foreword. In Greenberg, J., and Cohen, R. L. (ed.), Equity and Justice in Social Behavior, Academic Press, New York, pp. xi-xviii.

Huber, J., and Form, W. H. (1973). Income and Ideology: An Analysis of the American Political Formula, Free Press, New York.

Huber Rytina, J., Form, W. H., and Pease, J. (1970). Income and stratification ideology: Beliefs about the American opportunity structure. Am. J. Sociol. 75: 703-716.

Jasso, G., and Rossi, P. H. (1977). Distributive justice and earned income. Am. Sociol. Rev. 42: 639-651.

Kluegel, J. R., and Smith, E. R. (1981). Beliefs about stratification. Ann. Rev. Sociol. 7: 29-56.

Kluegel, J. R., and Smith, E. R. (1986). Beliefs About Inequality: Americans' Views of What Is and What Ought to Be, Aldine de Gruyter, New York.

Lerner, M. J. (1987). Integrating societal and psychological rules of entitlement: The basic task of each social actor and fundamental problem for the social sciences. Soc. Justice Res. 1: $107-125$.

Lockwood, D. (1975). Sources in variation in working class images of society. In Bulmer, M (ed.), Working Class Images of Society, Routledge \& Kegan Paul, London, pp. 16-31.

Mackenzie, G. (1973). The Aristocracy of Labor. The Position of Skilled Craftsman in the American Class Structure, Cambridge University Press, Cambridge, U.K.

Mackenzie, G. (1974). The 'affluent worker' study: An evaluation and critique. In Parkin, F. (ed.), The Social Analysis of Class Structure, Tavistock, London, pp. 237-256.

Markovsky, B. (1985). Toward a multilevel distributive justice theory. Am. Sociol. Rev. 50: $822-839$.

Marshall, G., Newby, H., Rose, D., and Vogler, C. (1988). Social Class in Modern Britain, Hutchinson, London.

Marx, K., and Engels, F. (1984). The German Ideology: Part One, (Edited and with Introduction by C. J. Arthur), International Publishers, New York.

Miller, D. (1976). Social Justice, Clarendon Press, Oxford

Parkin, F. (1974). Strategies of social closure. In Parkin, F. (ed.), The Social Analysis of Class Structure, Tavistock, London, pp. 1-18.

Rafferty, J. A., and Hasenfeld, Y. (1992). A response to Emerson and Van Buren. Soc. Forces 71: $511-512$.

Rawls, J. (1973). A Theory of Justice, Oxford University Press, London.

Reich, C. A. (1964). The new property. Yale J. 73: 733-788.

Ritzman, R. L., and Tomaskovic-Devey, D. (1992). Life chances and support for equality and equity as normative and counternormative distribution rules. Soc. Forces 70: 745-763.

Roberts, K., Cook, F. G., Clark, S. C., and Semeonoff, E. (1977). The Fragmentary Class Structure, Heinemann, London.

Robinson, R. V., and Bell, W. (1978). Equality, Success, and Social Justice in England and the United States. Am. Sociol. Rev. 43: 125-143. 
Rossi, P. H., and Anderson, A. B. (1982). The factorial survey approach: An introduction. In Rossi, P. H., and Nock, S. L. (eds.), Measuring Social Judgments: The Factorial Survey Approach, Sage, Beverly Hills, pp. 9-15.

Rytina, S. (1986). Sociology and Justice. In Cohen, R. L. (ed.), Justice: Views from the Social Sciences, Plenum Press, New York, pp. 117-151.

Schaeffer, N. C., (1990). Principles of justice in judgments about child support. Soc. Forces 69: $157-179$.

Schwartz, S. (1975). The justice of need and the activation of humanitarian norms. J. Soc. Issues 31(3): 111-137.

Shepelak, N. J. (1989). Ideological stratification: American beliefs about economic justice. Soc. Justice Res. 3: 217-231.

Smith, K B., and Stone, L. H. (1989). Rags, riches, and bootstraps: Beliefs about the causes of wealth and poverty. Soc. Quart. 30: 93-107.

Steijn, A. J., and De Witte, M. (1992). De Januskop van de Industriële Samenleving: Technologie, Arbeid, en Klassen aan het Begin van de Jaren Negentig [The Janushead of the Industrial Society: Technology, Work, and Classes at the Beginning of the Nineties], Samson, Alphen a/d Rijn, The Netherlands.

Steijn, A. J., and De Witte, M. (1994). Class and image of society of Dutch workers. Int. J. Group Tensions 24: 219-235.

Svallfors, S. (1991). The politics of welfare policy in Sweden: Structural determinants and attitudinal cleavages. Br. J. Sociol. 42: 609-634.

Törnblom, K. (1992). The social psychology of distributive justice. In Scherer, K. R. (ed.), Justice: Interdisciplinary Perspectives, Cambridge University Press, Cambridge, U.K, pp. 177-237.

Törnblom, K Y., and Foa, U. G. (1983). Choice of a distribution principle: Crosscultural evidence on the effects of resources. Acta Sociol. 26: 161-173.

Walster, E., and Walster, G. W. (1975). Equity and social justice. J. Soc. Issues 31: 21-45.

Weakliem, D. (1993). Class consciousness and political change: Voting and political attitudes in the British working class, 1964 to 1970 . Am. Sociol. Rev. 58: 382-397.

Weber, M. (1968). In Roth, G., and Wittich, C. (eds.), Economy and Society. An Outline of Interpretive Sociology, Bedminster Press, New York.

Wright, E. O. (1979). Class Structure and Income Determination, Academic Press, New York.

Wright, E. O. (1989). The comparative project on class structure and class consciousness: An overview. Acta Sociol. 32: 3-22. 